\title{
Pengaruh Intensitas Matahari Terhadap Karakteristik Sel Surya Jenis Polycristaline Menggunakan Regresi Linear
}

\author{
Andi Makkulau $^{1}$; Samsurizal ${ }^{2}$ Miftahul Fikri $^{3}$; Christiono $^{4}$ \\ 1, 2, 3, 4Teknik Elektro, Institut Teknologi PLN \\ Jl. Lingkar Luar Barat, Duri Kosambi, Jakarta Barat \\ 1 andi.mk@itpln.ac.id
}

\begin{abstract}
Renewable energy sources have both renewable and sustainable properties and the utilization of renewable energy sources is a continuously developed alternative. One of the technologies that can utilize renewable energy is polycrystalline solar cells. Solar cells are technology that converts sunlight energy into electrical energy. This technology is very potentially applied in Indonesia that has a tropical climate, but the main problem of this system is the power instability generated. The power produced relies heavily on the intensity of the sun received by the solar panels. The intensity of the solar radiation received by the solar panels can be maximised by installing solar panels, with a precise tilt angle. In research acquired the relationship between irradiation and current correlates of $R=0.7251$. From the correlation value above indicates that there is a strong link and is directly proportional between irradiation and the current obtained. The acquired Model needs to be seen its accuracy, in which case it will be used Mean Absolute Percent Error So it is obtained by 26.5\%. This indicates that the model is good enough.
\end{abstract}

Keywords: : Photovoltaic, Solar Radiation, Slope Angle, Electric Current

\begin{abstract}
ABSTRAK
Sumber energi terbarukan mempunyai sifat terbarukan serta berkesinambungan dan pemanfaatan sumber energi terbarukan merupakan alternatif yang terus dikembangkan. Salah satu teknologi yang dapat memanfaatkan energi terbarukan yaitu sel surya polycrystalline. Sel surya merupakan teknologi yang mengubah energi cahaya matahari menjadi energi listrik. Teknologi ini sangat berpotensi diterapkan di Indonesia yang mempunyai iklim tropis, tetapi permasalahan utama dari sistem ini adalah ketidakstabilan daya yang dihasilkan. Daya yang dihasilkan sangat bergantung pada intensitas matahari yang diterima oleh panel surya. Intensitas radiasi matahari yang diterima oleh panel surya dapat dimaksimalkan dengan cara memasang panel surya, dengan sudut kemiringan yang tepat. Pada penelitian diperoleh hubungan antara iradiasi dan arus berkorelasi sebesar $r=0.7251$. Dari nilai korelasi di atas menunjukkan bahwa adanya kaitan yang kuat dan berbanding lurus antara iradiasi dan arus yang diperoleh. Model yang diperoleh perlu dilihat akurasinya, dalam hal ini akan digunakan Mean Absolute Percent Error sehingga diperoleh sebesar 26,5\%. Hal ini menunjukkan bahwa model sudah cukup baik.
\end{abstract}

Kata Kunci: Panel Surya, Intensitas Radiasi Matahari, Sudut Kemiringan, Arus Listrik 


\section{KILAT}

Vol. 10, No. 1, April 2021, P-ISSN 2089-1245, E-ISSN 2655-4925

DOI: https://doi.org/10.33322/kilat.v10i1.994

\section{PENDAHULUAN}

Pemenuhan kebutuhan energi listrik saat ini masih bergantung pada sumber energi fosil yang ketersediaanya terbatas. Oleh karna itu dimasa mendatang pemanfaatan sumber energi terbarukan merupakan alternatif yang perlu terus dikembangkan. Indonesia sebagai negara kepulauan dengan jumlah penduduk yang saat ini berjumlah \pm 240 juta jiwa mempunyai masalah rasio elektrifikasi yang relatif masih rendah, khususnya untuk wilayah Indonesia bagian Timur, dibandingkan dengan infrastuktur kelistrikan di pulau Jawa [1]. Solusinya adalah dengan lebih memanfaatkan potensi energi terbarukan lokal, seperti pembangkit tenaga surya, mikrohidro, dan geothermal.

Sumber energi terbarukan mempunyai sifat terbarukan dan berkesinambungan. Pembangkit Listrik Tenaga Surya (PLTS) menggunakan energi matahari sebagai sumber energi terbarukan. Komponen utama dari PLTS adalah sel surya (sel photovoltaic) [2]. PLTS umumnya digunakan di daerah yang memiliki radiasi matahari yang tinggi dan daerah yang belum terjangkau oleh listrik PLN. Di Indonesia tipe sel surya yang banyak digunakan adalah tipe polikristalin silicon. Ada beberapa parameter lingkungan yang dapat mempengaruhi kinerja dari sel surya, diantaranya, perubahan temperatur, intensitas radiasi matahari, tertutupnya sebagian permukaan sel surya (bayangan) [3].

Dalam Jurnal Energi dan Kelistrikan yang berjudul "Analisis Pengaruh Sudut Kemiringan Terhadap Arus Keluaran Pada Photovoltaic Dengan Menggunakan Regretion Quadratic Method" terdapat pengaruh Sudut kemiringan terhadap intensitas matahari yang mempengaruhi output dari PV array sehingga untuk mendeteksi efek tersebut digunakan metode observasi langsung dan validaasi data dengan persamaan matematik [4]. Pada penelitian lain berjudul Evaluasi Sudut Kemiringan Terhadap Pengaruh Irradiance Pada Array Photovoltaic Jenis Monocristalline" yang diterbitkan pada Jurnal Setrum-FT Untirta Vol.8.1 dalam satu sistem PLTS didapatkan hasil bahwa semakin besar penyimpangan sudut pada PV array, maka semakin menurun kinerja PLTS tersebut [5]. Sedangkan pada penelitian berjudul Characteristics of Temperature Changes Measurement on Photovoltaic Surfaces Against Quality of Output Current on Solar Power Plants, menghasilkan arus optimal adalah pada 1,92 Ampere, suhu optimum pada $37,4^{\circ} \mathrm{C}$, dan nilai tukar tertinggi adalah pada 2,08 Ampere sedangkan suhu pada permukaan sel surya adalah pada $37,4^{\circ} \mathrm{C}$. Sesuai dengan hasil yang telah dilakukan dengan menggunakan persamaan regresi matematis yaitu persamaan statistik regresi kuadrat, dapat diketahui bahwa karakteristik sel surya memiliki tenaga kerja yang efisien adalah sekitar $37,4{ }^{\circ} \mathrm{C}[6]$. Didapatkan pula pengaruh irradiance pada percobaan tersebut.

Mengingat ada beberapa parameter lingkungan yang dapat mempengaruhi kinerja sel surya yang salah satunya adalah bayangan, maka rumusan masalah pada penelitian ini adalah bagaimana pengaruh sudut kemiringan dan intensitas matahari terhadap karakteristik sel surya jenis polycristaline [3]. Sehingga pada penelitian kali ini meneruskan penelitian mengenai "Pengaruh Sudut Kemiringan Dan Intensitas Matahari Terhadap Karakteristik Sel Surya Jenis Polycristaline" terhadap pengaruh irradiance terbaik terhadap kinerja PLTS dengan Jenis yang berbeda sehingga dapat memberikan informasi tambahan mengenai pengayaan bahan ajar Sumber daya energi.

\section{METODE / PERANCANGAN PENELITIAN}

Dalam menyelesaikan penelitian ini menggunakan beberapa tahap untuk menganalisis pengaruh intensitas matahari terhadap karakteristik sel surya jenis polycristaline:

- Pengumpulan data dan informasi berupa materi yang dibutuhkan.

- Melakukan pengukuran terhadap modul surya Polycristaline.

- Mengklasifikasikan data pengukuran yang telah didapat dari pengukuran di lapangan.

- Menganalisa dengan menggunakan model matematis 
- Metode observasi data dengan cara mengadakan pengamatan secara langsung terhadap objek kegiatan yang berhubungan dengan penelitian.

- Metode wawancara dengan cara mengumpulkan data dengan tanya jawab sambil bertatap muka antara peneliti dan nara sumber.

- Metode dokumentasi dengan cara pengumpulan data dengan cara mempelajari, memahami, data bersumber dari catatan atau dokumen yang tersedia.

\subsection{Diagram Alur Penelitian}

Pada penelitian ini diagram alur kerja penelitian dapat dilihat pada gambar 1.

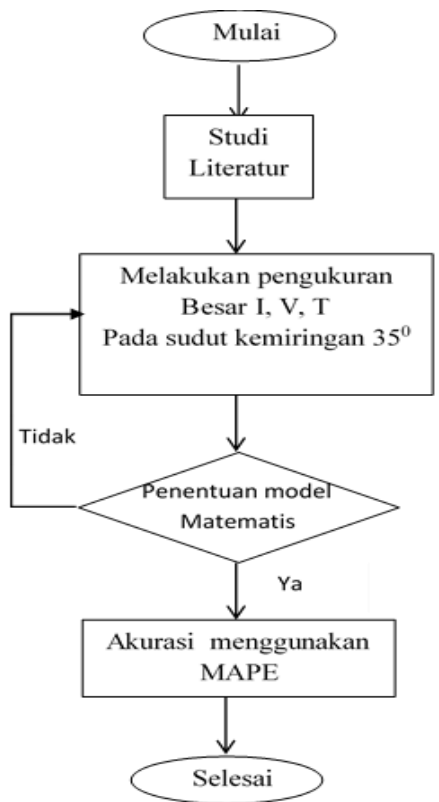

Gambar 1. Diagram Alur Penelitian

\subsection{Data Teknik Peralatan dan Analisis}

Modul surya yang digunakan dalam penelitian ini memiliki spesifikasi seperti yang ditunjukkan tabel 1 .

Tabel 1. Spesifikasi Modul Surya

\begin{tabular}{|l|c|c|}
\hline \multicolumn{3}{|c|}{ Solar Polycrystalline } \\
\hline Maximum Power & Pmax & $100 \mathrm{~W}$ \\
\hline Maximum Power Voltage & Vmp & $17.1 \mathrm{~V}$ \\
\hline Maximum Power Current & Imp & $5.84 \mathrm{~A}$ \\
\hline Open Circuit Voltage & Voc & $21.2 \mathrm{~V}$ \\
\hline Short Circuit Current & Isc & $6.46 \mathrm{~A}$ \\
\hline
\end{tabular}

Sumber : Solar Panel ICA Polycrystaline

Pengambilan data yang telah dilaksanakan selama kurun waktu kurang lebih 40 hari dengan metode pengambilan data yang dilakukan adalah observasi langsung di lapanagan sehingga data yang di peroleh adalah murni data hasil pengambilan secara langsung dan real time dengan durasi 


\section{KILAT}

Vol. 10, No. 1, April 2021, P-ISSN 2089-1245, E-ISSN 2655-4925

DOI: https://doi.org/10.33322/kilat.v10i1.994

pencatatan data di lakukan tiap 10 menit sekali dalam range waktu 8 jam perhari, Adapun data yang diperoleh antara lain adalah data arus keluaran dari modul surya, tegangan keluaran modul surya, irradiasi pancaran sinar matahari, dan suhu pada permukaan modul surya dari tiap-tiap perubahan sudut kemiringan modul surya. Adapun data eksternal yang kami ambil yaitu data perubahan iklim lokal selama proses pengambilan data yang memiliki pengaruh secara langsung terhadap perubahan karakteristik data dari modul surya.

Dalam Analisis regresi dikenal dua macam variabel atau peubah yaitu variabel bebas (independent variable) adalah suatu variabel yang nilainya telah diketahui dan variabel tidak bebas (dependent variable) adalah variabel yang nilainya belum diketahui dan yang akan diramalkan. Suatu variabel dapat diramalkan dari variabel lain apabila antara variabel yang diramalkan (dependent variabel) dengan variabel yang nilainya diketahui (independent variabel) terdapat hubungan atau korelasi yang signifikan. Korelasi antara variabel bebas dengan variabel tidak bebas dapat dilukiskan dalam suatu garis. Garis ini yang disebut garis regresi. Garis regresi mungkin merupakan garis lurus (linier) yang disebut regresi linier.

Regresi linier dapat di bedakan menjadi dua bagian, yaitu regresi linier sederhana dan regresi linier berganda. Regresi linier sederhana mengamati pengaruh satu variabel bebas (independent variable) terhadap variabel tidak bebas (dependent variable). Secara matematis regresi linier sederhana dapat dituliskan dalam bentukpersamaan. Jika variabel $X$ yang diketahui terlebih dahulu dan kemudian $\mathrm{Y}$ ditentukan berdasarkan $\mathrm{X}$ ini, maka ditentukan hubungan $Y=f(X)$. Rumusan hubungan ini lebih dikenal dengan nama Regresi $\mathrm{Y}$ atas $\mathrm{X}$. Jika regresi $\mathrm{Y}$ atas $\mathrm{X}$ ini linear, maka persamaannnya dapat dituliskan dalam bentuk berikut [12]:

$$
Y=a+b X
$$

Dengan:

$\mathrm{Y}=$ variabel yang diramalkan (dependent variable)

$\mathrm{X}=$ Variabel yang diketahui (Independent variable)

$a=$ besarnya nilai $\mathrm{Y}$ pada saat nilai $\mathrm{X}=0$

$b=$ besarnya perubahan nilai $\mathrm{Y}^{\wedge}$ apabila nilai $\mathrm{X}$ bertambah satu satuan, yang disebut koefisien regresi.

Untuk mencari nilai-nilai koefisien regresi $b$ atau nilai $a$ kita dapat menggunakan metode kuadrat terkecil.

Untuk mendapatkan akurasi relatif digunakan persamaan untuk mengetahui persentase penyimpangan dari suatu model, dalam hal ini akan digunakan persamaan MAPE [3].

$$
M A P E=\frac{1}{n} \sum_{t=1}^{n}\left|\frac{Y_{t}-\hat{Y}_{t}}{Y_{t}}\right| \times 100
$$

\section{HASIL DAN PEMBAHASAN}

Perancangan dan Pembuatan konstruksi modul uji sebagai sarana dalam memudahkan proses pengambilan data observasi penelitian, dimana komponen-komponen pendukung lainnya di buat dalam satu rangkaian modul seperti panel surya yang dapat ditentukan setiap sudut kemiringannya $35^{\circ}$, dimana data sudut yang kami tentukan merupakan nilai sudut kemiringan dari modul surya 
terhadap paparan radiasi sinar matahari yang dianggap efisien di wilayah lingkup kampus Institut Teknologi PLN, berdasarkan dari penelitian sebelumnya seperti yang ditunjukkan gambar 2 .

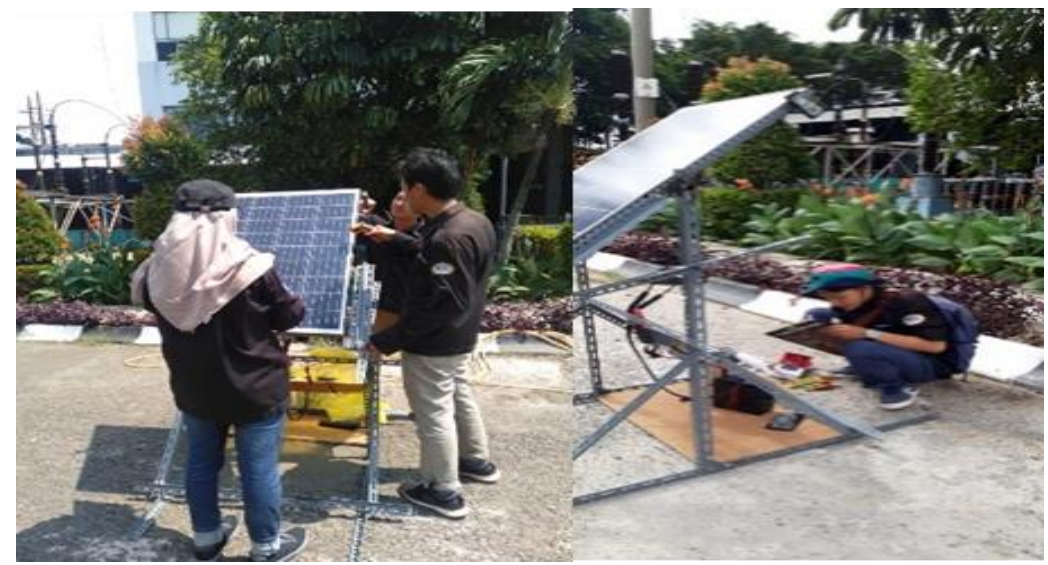

Gambar 2. Pengujian dan Pengambilan Data

Adapun hasil yang telah diperoleh berdasarkan pengukuran secara langsung dengan modul uji yang telah kami buat. Dimana data hasil pengukuran tersebut peneliti kelompokkan dengan beberapa kelompok data yang dapat peneliti sajikan dalam bentuk tinjauan data sementara hasil pengukuran yang telah peneliti laksanakan, Adapun hasil dari pengambilan data ini belum sepenuhnya selesai dan masih ada beberapa tahap sehingga peneliti dapat memberikan hasil penelitian yang sesuai dengan apa yang diharapkan. Pada penelitian ini, data yang bersesuaian dengan persamaan regresi pada persamaan (1) adalah iradiasi $\left(\mathrm{W} / \mathrm{m}^{2}\right)$ bersesuaian dengan variabel bebas $(\mathrm{X})$ dan arus $(\mathrm{A})$ bersesuaian dengan variabel bergantung $(\mathrm{Y})$. Adapun data rata-rata pengamatan yang dilakukan dikampus IT-PLN selama 40 hari. Dari hasil pengukuran dan pengujian pengaruh iradiasi terhadap arus, didapat grafik seperti yang ditunjukkan gambar 3 .

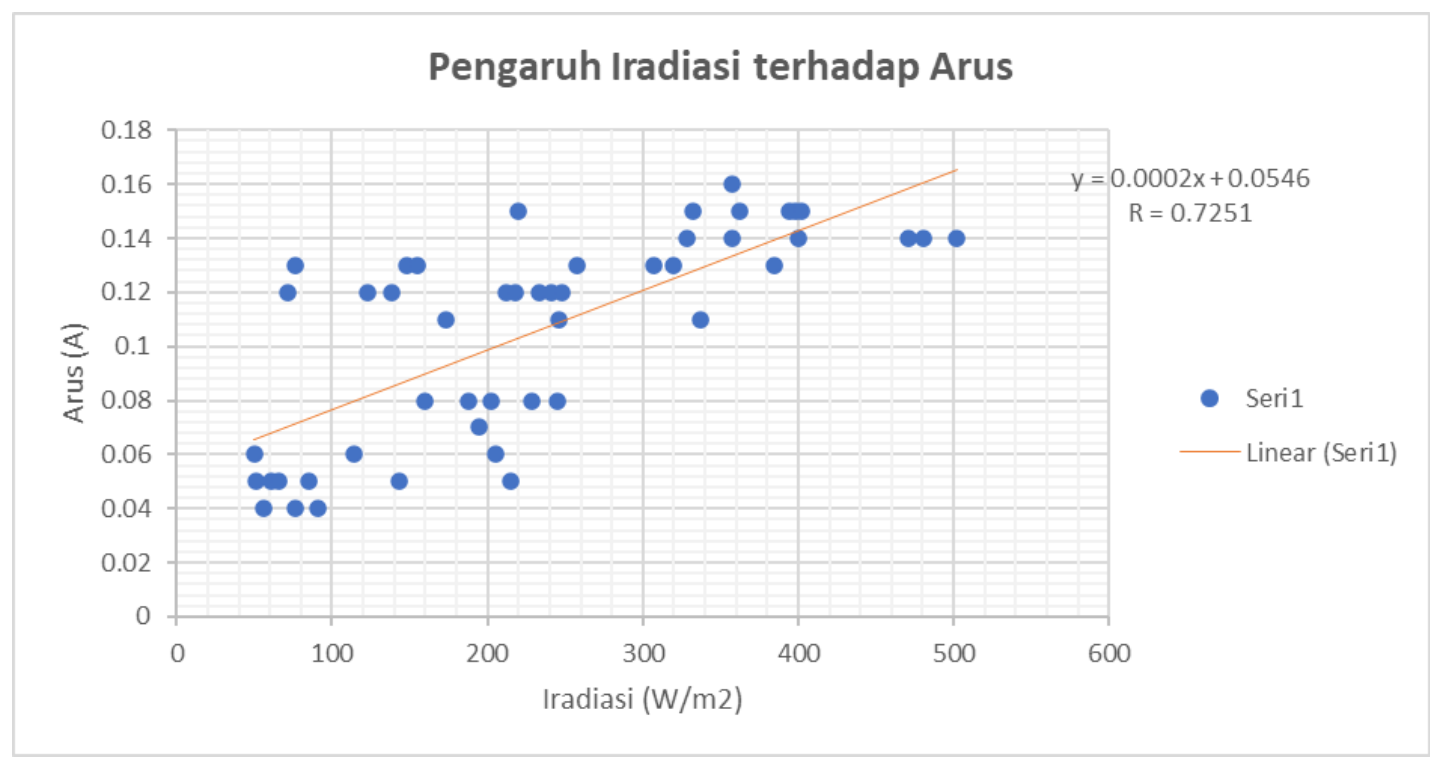

Gambar 3. Grafik Iradiasi Terhadap Arus

Data hasil pengujian dan pengukuran iradiasi dan arus pada PLTS disajikan pada tabel 2. 


\section{KILAT}

Vol. 10, No. 1, April 2021, P-ISSN 2089-1245, E-ISSN 2655-4925

DOI: https://doi.org/10.33322/kilat.v10i1.994

Tabel 2. Data rata-rata iradiasi dan arus pada PLTS

\begin{tabular}{|c|c|c|c|c|c|c|c|}
\hline No. & Jam & $\begin{array}{c}\text { Iradiasi - W/m } \mathrm{m}^{2} \\
(\mathbf{X})\end{array}$ & Arus-A (Y) & No. & Jam & $\begin{array}{c}\text { Iradiasi - W/m } \mathrm{m}^{2} \\
(\mathbf{X})\end{array}$ & Arus-A (Y) \\
\hline 1 & $08.00-08.10$ & 61 & 0.05 & 25 & $12.00-12.10$ & 394 & 0.15 \\
\hline 2 & $08.10-08.20$ & 51 & 0.05 & 26 & $12.10-12.20$ & 398 & 0.15 \\
\hline 3 & $08.20-08.30$ & 50 & 0.06 & 27 & $12.20-12.30$ & 328 & 0.14 \\
\hline 4 & $08.30-08.40$ & 56 & 0.04 & 28 & $12.30-12.40$ & 402 & 0.15 \\
\hline 5 & $08.40-08.50$ & 66 & 0.05 & 29 & $12.40-12.50$ & 362 & 0.15 \\
\hline 6 & $08.50-09.00$ & 76 & 0.04 & 30 & $12.50-13.00$ & 357 & 0.14 \\
\hline 7 & $09.00-09.10$ & 85 & 0.05 & 31 & $13.00-13.10$ & 357 & 0.16 \\
\hline 8 & $09.10-09.20$ & 91 & 0.04 & 32 & $13.10-13.20$ & 320 & 0.13 \\
\hline 9 & $09.20-09.30$ & 114 & 0.06 & 33 & $13.20-13.30$ & 76 & 0.13 \\
\hline 10 & $09.30-09.40$ & 143 & 0.05 & 34 & $13.30-13.40$ & 71 & 0.12 \\
\hline 11 & $09.40-09.50$ & 160 & 0.08 & 35 & $13.40-13.50$ & 258 & 0.13 \\
\hline 12 & $09.50-10.00$ & 195 & 0.07 & 36 & $13.50-14.00$ & 241 & 0.12 \\
\hline 13 & $10.00-10.10$ & 205 & 0.06 & 37 & $14.00-14.00$ & 233 & 0.12 \\
\hline 14 & $10.10-10.20$ & 215 & 0.05 & 38 & $14.10-14.20$ & 212 & 0.12 \\
\hline 15 & $10.20-10.30$ & 188 & 0.08 & 39 & $14.20-14.30$ & 218 & 0.12 \\
\hline 16 & $10.30-10.40$ & 202 & 0.08 & 40 & $14.30-14.40$ & 248 & 0.12 \\
\hline 17 & $10.40-10.50$ & 228 & 0.08 & 41 & $14.40-14.50$ & 246 & 0.11 \\
\hline 18 & $10.50-11.00$ & 245 & 0.08 & 42 & $14.50-15.00$ & 307 & 0.13 \\
\hline 19 & $11.00-11.10$ & 337 & 0.11 & 43 & $15.00-15.10$ & 332 & 0.15 \\
\hline 20 & $11.10-11.20$ & 471 & 0.14 & 44 & $15.10-15.20$ & 220 & 0.15 \\
\hline 21 & $11.20-11.30$ & 481 & 0.14 & 45 & $15.20-15.30$ & 148 & 0.13 \\
\hline 22 & $11.30-11.40$ & 502 & 0.14 & 46 & $15.30-15.40$ & 123 & 0.12 \\
\hline 23 & $11.40-10.50$ & 400 & 0.14 & 47 & $15.40-15.50$ & 138 & 0.12 \\
\hline 24 & $11.50-12.00$ & 385 & 0.13 & 48 & $15.50-16.00$ & 173 & 0.11 \\
\hline
\end{tabular}

Pada gambar 1. Didapat grafik bahwa semakin besar iradiasi, semakin besar arus yang di dapat. Hal ini menunjukkan kaitan antara iradiasi dan arus yang diperoleh berbanding lurus. Adapun persamaan regresi yang diperoleh antara iradiasi( $\mathrm{x})$ dengan arus(y) adalah $\mathrm{y}=0.0002 \mathrm{x}+0.0546$. Pada persamaan tersebut terlihat bahwa gradien sebesar 0.0002 yang artinya penambahan iradiasi sebesar $100 \mathrm{~W} / \mathrm{m}^{2}$ akan menyebabkan arus bertambah sebesar 0.02A. Adapun hubungan antara iradiasi dan arus berkorelasi sebesar $\mathrm{R}=0.7251$. Di mana koefisien korelasi diantara -1 sampai dengan 1 , dengan -1 berarti memiliki hubungan yang sangat kuat dan berbanding terbalik, nilai korelasi 1 berarti memiliki hubungan yang sangat kuat dan berbanding lurus, serta nilai korelasi 0 berarti memiliki hubungan yang sangat rendah [7]. Dari nilai korelasi di atas menunjukkan bahwa adanya kaitan yang kuat dan berbanding lurus antara iradiasi dan arus yang diperoleh.

Model yang diperoleh perlu dilihat akurasinya, dalam hal ini akan digunakan MAPE. MAPE merupakan ukuran akurasi relatif yang digunakan untuk mengetahui persentase penyimpangan dari suatu model. Pada penelitian ini diperoleh MAPE dengan menggunakan persamaan 2 didapat nilai sebesar 26,5\%. Hal ini menunjukkan bahwa model sudah cukup baik, tetapi agar diperoleh model yang lebih baik lagi baik dilihat dari MAPE maupun korelasi model, maka faktor-faktor lain yang mempengaruhi arus perlu disertakan pada penelitian selanjutnya. 


\section{KESIMPULAN DAN SARAN}

Berdasarkan penelitian yang dilakukan, dapat disimpulkan bahwa pengaruh iradiasi terhadap arus menggunakan model persamaan regresi linear sudah cukup baik dengan tingkat korelasi $\mathrm{R}=0.7251$ yang berarti bahwa $72,51 \%$ arus yang didapat dipengaruhi oleh iradiasi dan sisanya sebesar 27,49\% dipengaruhi oleh factor lain. Adapun MAPE yang diperoleh sebesar 26,5\%, walaupun termasuk dalam kategori cukup baik tetapi perlu dilakukan pengembangan seperti menggunakan regresi berganda sehingga hasil yang diperoleh diharapkan dapat lebih baik lagi. Dalam penelitian ini dapat disimpulkan bahwa dengan menggunakan regeresi liner iradiasi sangat yang terjadi sangat mempengaruhi arus keluaran pada photovoltaic. Adapun hubungan antara iradiasi dan arus berkorelasi sebesar $\mathrm{R}=0.7251$. Di mana koefisien korelasi diantara -1 sampai dengan 1 , dengan -1 berarti memiliki hubungan yang sangat kuat dan berbanding terbalik, nilai korelasi 1 berarti memiliki hubungan yang sangat kuat dan berbanding lurus, serta nilai korelasi 0 berarti memiliki hubungan yang sangat rendah. Perubahan sudut kemiringan dari modul surya juga berperan penting dalam mempengaruhi kinerja dari modul surya jenis polycristaline. Faktor iklim juga sangat berpengaruh besar terhadap kualitas keluaran dari modul surya

\section{UCAPAN TERIMAKASIH}

Penulis mengucapkan terima kasih kepada Institut Teknologi PLN melalui LPPM yang telah mendanai dan memberi dukungan yang membantu pelaksanaan penelitian dan atau penulisan artikel ini.

\section{DAFTAR PUSTAKA}

[1] APAMSI. (2013) Pengembangan PLTS di Indonesia, Yogyakarta.

[2] A. Duffie. (2008) Solar Engineering Of Thermal Processes, Newyork: John Wiley \& Sons.

[3] S. Makridakis, W. S.C, M. V and E. McGee. (1999). Metode dan Aplikasi Peramalan, Jakarta: Erlangga.

[4] Samsurizal, A. Makkulau and Christiono. (2018) "Analisis Pengaruh Sudut Kemiringan Terhadap Arus Keluaran Pada Photovoltaic Dengan Menggunakan Regretion Quadratic Method," Jurnal Energi dan Kelistrikan, no. 2 vol.10, pp. 137-144.

[5] Samsurizal, Christiono and A. Makkulau. (2019). "Evaluasi Sudut Kemiringan Terhadap Pengaruh Irradiance Pada Array Photovoltaic Jenis Monocristalline," Jurnal SETRUM, no. 1. vol.8, pp. 28-34.

[6] A. Makkulau, Christiono and Samsurizal. (2019) "Characteristics of Temperature Changes Measurement on Photovoltaic Surfaces Against Quality of Output Current on Solar Power Plants," International Conference on Technologies and Policies in Electric Power \& Energy, IEEE, vol. doi: 10.1109/IEEECONF48524.2019.9102630., pp. 1-4.

[7] Sigiyono. (2016) Metode Penelitian Kuantitatif, Kualitatif dan R\&D, Bandung: Alfabeta.

[8] K. H. Khwee. (2013). "Pengaruh Temperatur Terhadap Kapasitas Daya Panel Surya (Studi Kasus: Pontianak)," Jurnal ELKHA, no. 2 vol.5.

[9] F. Pakaja and A. Naba. (2012). "Purwanto, Peramalan Penjualan Mobil Menggunakan Jaringan Syaraf Tiruan dan Certainty Factor," EECCIS, no. 1 vol.6,

[10] Azzahra, S., Samsurizal, S., Christiono, C., \& Fikri, M. (2020). Pemasangan Lampu Jalan dan Pembangunan Pembangkit Listrik Berbasis Solar Cell Sebagai Prototype Pembelajaran Energi Terbarukan Di MA Al-Khairiyah Rancaranji. Jurnal Terang, 3(1), 100-105.

[11] Christiono, Samsurizal, R. Pratama, T. Ratnasari, M. Fikri. (2019). Penyuluhan Pemanfaatan Energi Terbarukan (PLTS) di SMP IT Almaka Jakarta. Jurnal Terang, 2 (1), 10-15. 


\section{KILAT}

Vol. 10, No. 1, April 2021, P-ISSN 2089-1245, E-ISSN 2655-4925

DOI: https://doi.org/10.33322/kilat.v10i1.994

[12] Kurniawan, R. (2016). Analisis regresi. Prenada Media.

[13] Permatasari, A. I., \& Mahmudy, W. F. (2015). Pemodelan regresi linear dalam konsumsi Kwh listrik di Kota Batu menggunakan algoritma genetika. DORO Repos. J. Mhs. PTIIK Univ. Brawijaya, 5(14), 1-9.

[14] Setiawan, B. (2017). Teknik Hitung Manual Analisis Regresi Linear Berganda Dua Variabel Bebas.

[15] Antonov, A., dan Rahman, A. R. (2015). Rakiraan Dan Analisa Kebutuhan Energi Listrik Provinsi Sumatera Barat Hingga Tahun 2024 Dengan Metode Analisis Regresi Linear BergandA. Jurnal Teknik Elektro, 4(2).

[16] Rumawan, F. H., Muslimin, M., \& Ba'ba, I. (2019). Peramalan Kebutuhan Daya Listrik Jangka Menengah (2019-2022) Kota Samarinda Dengan Metode Regresi Linear. In Prosiding Seminar Nasional Teknologi, Inovasi dan Aplikasi di Lingkungan Tropis Vol. 2, No. 1, pp. 202-210. 